\title{
The God of the Gaps, Natural Theology and Intelligent Design
}

\section{Kojonen, Erkki Vesa Rope}

2016

Kojonen , E V R 2016 , ' The God of the Gaps, Natural Theology and Intelligent Design ' , The journal of analytic theology , vol. 4 , pp. 291-316 . https://doi.org/10.12978/jat.2016-4.041708101413a

http://hdl.handle.net/10138/172829

https://doi.org/10.12978/jat.2016-4.041708101413a

publishedVersion

Downloaded from Helda, University of Helsinki institutional repository.

This is an electronic reprint of the original article.

This reprint may differ from the original in pagination and typographic detail.

Please cite the original version. 


\title{
The God of the Gaps, Natural Theology, and Intelligent Design
}

\author{
Erkki V. R. Kojonen \\ University of Helsinki
}

\begin{abstract}
The "God of the gaps" critique is one of the most common arguments against design arguments in biology, but is also increasingly used as a critique of other natural theological arguments. In this paper, I analyze four different critiques of God of the gaps arguments and explore the relationship between gaps arguments and similar limit arguments. I conclude that the critique of the God of the gaps is substantially weaker than is commonly assumed, and dismissing ID's biological arguments should rather be based on criticizing the premises of these arguments.
\end{abstract}

\section{Introduction}

The term "God of the gaps" is used in many ways, usually as a critique against some theistic explanation. This critique is most frequently made against creationism and Intelligent Design (ID), when phenomena like the origin of life are explained as a divine miracle, or at least as the product of an unidentified intelligent designer. ${ }^{1}$ The critique of God of the gaps is often made in a cursory manner, and yet is believed to be so strong that (as Del Ratzsch notes) "merely labeling an explanation as 'God-of-the-gaps' is often taken to constitute an unanswerable refutation of it" (Ratzsch 2001, 47; Larmer 2002). However, the phrase "God of the gaps" (GOG) is understood in many different ways, and the same critique is made even against all theistic argumentation by some atheists. In such critiques, it has been argued that all theistic explanations are examples of GOG, and we should expect science to ultimately banish GOG altogether (e.g. Stenger 2004, 182). Proponents of ID themselves vigorously deny the charge that their argument is a God of the gaps argument. ${ }^{2}$

In this situation, it is important to clarify just what is meant by GOG arguments and what might or might not be the problem with them. (Similarly

\footnotetext{
1 The critique of the ID movement's design argument as a "God of the gaps" argument is commonly presented by both theistic and naturalistic critics of ID. For examples, see the edited volumes (Dembski \& Ruse 2004, 67, 142, 238); (Pennock 2001, 158-159, 184-185); (Petto \& Godfrey 2007, 309-338, 416-417); (Comfort 2007, 86); and (Young \& Edis 2006, 3-5, 24-25, 178182). For analysis of the relationship between ID and creationism, see (Kojonen 2016, ch. 2).

${ }^{2}$ Indeed, though most proponents of ID explicitly identify the designer with the Christian God, their design arguments are minimalistic and they believe that the identification of the designer is a separate step. See (Kojonen 2016, ch. 3). This means that the phrase "a designer of the gaps" might be more apt to describe ID. Nevertheless, as the term "God of the gaps" is so commonly used in the debate, I will also use it here.
}

Journal of Analytic Theology, Vol. 4, May 2016 10.12978/jat.2016-4.041708101413a

(C)2016 Erkki V. R. Kojonen • (C) 2016 Journal of Analytic Theology 
Plantinga 1997, Rusbult 2004). The main purpose of this article is to clarify the discussion of gaps arguments among theists, and to clarify the relevance of the term "God of the gaps" for the debate over Intelligent Design. I will do this by analyzing four different critiques of GOG arguments. The first two critiques are philosophical whereas the latter two are theological. The first critique (1) is that GOG arguments are arguments from ignorance, meaning that in them some theistic explanation is argued to be correct on the basis that we have no scientific explanation of the phenomena. In this case the arguments would be logically fallacious. The second critique (2) is more modest than the first: it claims simply that GOG arguments invoke God as an explanation at a point where it would be more reasonable to look for scientific explanations based on our past experience. The third critique (3) is that GOG arguments presuppose a bad theology of divine action. The worry is that GOG arguments wrongly emphasize miraculous divine action and minimize divine action in and through natural processes. The fourth critique (4) of GOG arguments is that they are apologetically and pastorally dangerous, meaning that they threaten the outward credibility and inward stability of religious faith.

\section{"God of the gaps" arguments as arguments from ignorance}

The critique of ID as an argument from ignorance is common in the literature, particularly in popular-level treatments. For example, Richard Dawkins argues against ID as follows:

admissions of ignorance and temporary mystification are vital to good science. It is therefore unfortunate, to say the least, that the main strategy of creation propagandists is the negative one of seeking out gaps in scientific knowledge and claiming to fill them with 'intelligent design' by default. ... It is precisely the fact that ID has no evidence of its own, but thrives like a weed in gaps left by scientific knowledge, that sits uneasily with science's need to identify and proclaim the very same gaps as a prelude to researching them. $(2006,152-153)$

Here Dawkins claims that proponents of ID argue for design based simply on gaps in scientific knowledge, and our present inability to explain all of life's evolution naturalistically.

Arguing merely based on ignorance is commonly understood to be logically fallacious. For example, Copi and Cohen define the argument from ignorance as "the mistake that is committed whenever it is argued that a proposition is true simply on the basis that it has not been proved false, or that it is false because it has not been proved true" $(1990,93)$. This argument is used against ID: not knowing how something could be explained naturalistically does not necessarily imply that there is no natural explanation for the thing. In scientific reasoning, the critique of different theories and alternative explanations is obviously important-scientific journals are full of such critiques. However, the failure to 
develop a detailed, natural explanation for the origin of life that could be repeated in the laboratory, for example, does not in itself make supernatural design a good explanation for the origin of life. It is argued that in the absence of a powerful ID argument, we should wait for a naturalistic explanation or simply withhold judgment rather than believe in ID (Blackstone 1997).

However, it is actually quite difficult to find examples in the literature where someone seriously argues for the existence of God (or an unidentified intelligent designer) purely on the basis of our present ignorance of natural explanations for some phenomenon. One contemporary example which comes quite close is the argument from atoms, which occurs sometimes on the popular level. One source propagating the argument is the U.S. cartoonist Jack T. Chick's pamphlet "Big Daddy" (1991[1972]). The pamphlet takes the form of a comic book, but its arguments are meant to be serious. The significance of its arguments is further increased by the fact that it is probably "the most widely distributed anti-evolution booklet in history" (Moore \& Decker 2008, 56). The booklet features a college professor presenting evidence for evolution, which is refuted piece by piece by the brave creationist student who is the hero of the comic. When the hero finally has an opportunity to ask a question from the university professor, he argues that atoms could not hold together if it were not for the miraculous power of God. The argument is based on magnetism: positive charges repel one another, and so the protons forming the core of atoms should naturally repel one another. So what holds atoms together? The student's answer is that, quoting the Bible: "In Him [by Christ] all things hold together" (Col. 1:17, NIV). Here the argument of the pamphlet proceeds from a scientific mystery to finding the answer in what is made out to be a biblical understanding of God. Chick does not really provide a positive argument here, however. Rather, he simply claims victory for his theistic explanation based on the claimed failure of naturalistic explanations. Christian doctrine does posit that God upholds all things in existence through Christ, but there is no biblical justification for believing that the locus of this divine action is on a scientifically detectable level inside atoms, rather than on the metaphysical level.

The argument is also scientifically weak. It is now part of standard scientific theory that the strong nuclear force is of just the right strength to hold atoms together (Koperski 2015, 4.2.4.). Furthermore, even without this specific scientific theory, Chick's argument ignores the principle that the actions of different natural processes often balance one another. Chick's argument is similar to claiming that the flight of an airplane is a miracle, since gravity is constantly pulling the airplane downwards. But actually the forces of aerodynamics allow the airplane to fly and overcome the effects of gravity. Chick would need much further argumentation to show that atoms could not be held together by some natural force, even if it were presently unknown.

However, the argument from atoms has not been defended by proponents of ID. In searching through the ID literature, I have not found examples of major ID proponents arguing for ID simply on the basis of the current lack of natural scientific explanations. The closest contender is probably Phillip E. Johnson, the early visionary leader of ID, in his book Darwin on Trial (1991). Johnson spends most of his time in the book arguing that Darwinian evolutionary theory does not explain various features of life, and then declares that belief in creation wins by default. This might initially be interpreted as an argument from ignorance, but we 
need to take account of one of ID's core background beliefs: design is understood to be a highly commonsensical, intuitively obvious explanation of the features of biology. Proponents of ID often quote Dawkins' description of biology approvingly: "biology is the study of complicated things that give the appearance of having been designed for a purpose" (Dawkins 1991, 1; Behe 2006a, 264-265; Dembski 1999, 125; Meyer 2009, 20-22). For example, Michael J. Behe (2006a, 265) writes that "the overwhelming appearance of design strongly affects the burden of proof: in the presence of manifest design, the onus of proof is on the one who denies the plain evidence of his eyes." Once this background assumption is taken into account, Johnson's argument in Darwin on Trial no longer looks like an argument from ignorance. Rather than inferring design merely on the basis of the claimed failure of evolutionary explanations, Johnson is assuming design as an obviously logical and intuitively apparent explanation of biological life that does not even need to be argued. The evidence for ID is on the table at the outset, and evolution, not design, is perceived as the challenger. From this perspective, refuting the credibility of all alternatives means that design will continue to reign as the best explanation by default, and does not require any further arguments in its favor. ${ }^{3}$

Other proponents of ID also commonly appeal to a lack of good naturalistic explanations as part of their arguments, but they argue that we have good reason to believe that such natural explanations do not exist, rather than simply appealing to our current ignorance of natural explanations. ${ }^{4}$ Though their formulations of just why certain patterns of nature are evidence of intelligent design tend to be brief, usually proponents of ID are also more explicit about the positive argument for design than Johnson. The point is made succinctly by ID proponents Gonzales and Richards: "It's not simple improbability that leads us to believe there's something fishy that needs explaining. It's the presence of a telling pattern, a pattern we have some reason to associate with intelligent agency" $(2005,303) .5$ In the ID movement's arguments, the critique of alternative explanations is important, but the conclusion of design is not thought to follow purely from the

\footnotetext{
${ }^{3}$ At this point it is interesting to note that cognitive scientists of religion often agree that interpreting nature as designed is natural for human minds. There is disagreement over whether the proposed naturalness of this interpretation implies that such intuitive interpretations of design are unreliable. On this discussion see (De Cruz \& De Smedt 2015) and (Kojonen 2016, chs. 7.6 and 7.7).

${ }^{4}$ As Larmer $(2002,131)$ puts the point: "we can ask whether those who appeal to gaps in our scientific understanding as evidence of supernatural intervention in the course of nature do so solely or simply on the basis of ignorance of how natural causes operate or rather on the basis of presumed positive knowledge of how natural causes operate."

${ }^{5}$ In his earlier work "The Blind Watchmaker," Dawkins also seems to initially acknowledge that a positive argument for design exists. Commenting on the work of William Paley, Dawkins begins by admitting that design arguments are based on an initially highly plausible reading of biology as the study of things that appear to be designed. Before Darwin, it was not easy for atheists to avoid the conclusion of design, though now Darwin makes this intellectually possible. But if all this is correct, then design arguments do not seem to be based merely on ignorance even in Dawkins's understanding. (Dawkins 1991, 1.) On a broader analysis of Dawkins, it becomes clear that even in the Blind Watchmaker, he argues against design based on metaphysical principles, not merely based on the scientific success of evolutionary biology. This is particularly clear in Dawkins's arguments regarding the origin of life. See Dawkins 1991, chapter 6. The argument there is a condensed version of what would later become Dawkins' main argument in the God Delusion: the improbability of God argument (Dawkins 2006, chapter 4; for a critique see Glass 2012).
} 
failure of explanations that are based on design. In addition to appealing to intuition, Behe also provides several formulations of how the apparently purposeful complexity of biology should be understood as evidence for a designer (2006a, 213-219). Stephen C. Meyer emphasizes the importance of formulating the design argument as an inference to the best explanation, where design must have some explanatory force, but the critique of alternative explanations is also important (2013).

William A. Dembski's eliminative design argument is another contender for an argument from ignorance. Dembski emphasizes the elimination of alternative explanations through determining an "universal probability bound" to eliminate chance events (1998, 167-174). Once it has been established that a given "specified" complex pattern is impossible to explain through the combination of natural laws and random chance, this leaves design as the only explanation left. This gives the impression that Dembski is constructing an argument from ignorance, where design wins as an explanation simply on the basis of the failure of other explanations (Pennock 2007, 326-333). However, Dembski does also attempt to provide other reasons for believing that "specified complexity" is evidence of design, and offers what he calls a "a straightforward inductive argument: In every instance where the complexity-specification criterion attributes design and where the underlying causal story is known (i.e. where we are not just dealing with circumstantial evidence, but where, as it were, the video camera is running and any putative designer would be caught red-handed), it turns out design actually is present; therefore, design actually is present whenever the complexity-specification criterion attributes design" (Dembski 2002, 25). Here Dembski is at least attempting to provide justification for believing that specified complexity is evidence of design, not merely evidence against natural explanations. I have analysed the logic of ID's arguments in detail elsewhere (Kojonen 2016, ch. 8).

Critics of ID forcefully disagree with the movement's claims about the empirical evidence and often also about the explanatory power of design. Sometimes calling ID a God of the gaps argument or "an argument from ignorance is simply another way of stating the conclusion that the argument is of poor quality. In an article titled "God of the gaps", Robert C. Pennock surveys ID's attempts at answering the God of the gaps-critique, and acknowledges that proponents of ID are presenting a design argument, and claim that certain patterns in nature are evidence of design. He also acknowledges the use of the inference to the best explanation in the movement's arguments. However, Pennock rejects the premises of the argument as weak and concludes that proponents of ID "have not advanced anything close to a positive scientific alternative to evolution, but have simply given an argument from ignorance.... In the end, their version is no more than a spurious god-of-the-gaps argument" (2007, 336). ${ }^{6}$ However, to me this use of the term "argument from ignorance" is not clear. Some argument's status as a bad argument (if the biological design argument indeed is a bad argument) does not mean that it is therefore also

\footnotetext{
${ }^{6}$ If we accept Pennock's argument, then William Paley (1743-1805) and his contemporaries also did not have any good reason to believe in design. I am more inclined to give more respect to Paley's argument. For some arguments for this position, see for example (Dawes 2007). For the contrary position that Humean arguments were sufficient to refute the design argument, see (Gliboff 2000).
} 
commits the fallacy of an argument from ignorance; there is more than one way for an argument to fail. ${ }^{7}$ I think the central matter to be criticized in ID's design argument should be the credibility of its premises rather than its overall logical structure.

\section{Limit Questions Good, God of the Gaps Bad?}

Though the Intelligent Design movement's arguments are not GOG arguments in the sense of committing the fallacy of being arguments from ignorance, the critique of the God of the gaps is also made in other, more modest terms. GOG arguments do not need to be understood as exemplifying some formal fallacy. Rather, it could simply be that an argument is a God of the gaps when a theological explanation is used at a point when it would be more reasonable to wait for scientific explanations. John Haught puts this point as follows against ID: "ID is a 'science stopper' since it appeals to a God-of-the-gaps explanation at a point in inquiry when there is still plenty of room for further scientific elucidation" (2004,

\footnotetext{
${ }^{7}$ It is also interesting to note that even current ignorance of something might in the right conditions be evidence against the existence of that something. In a good "argument from ignorance," it is not claimed simply that "because we do not know of something," therefore that something must not exist. Rather, it is argued that in proper conditions, absence of evidence can indeed be evidence of absence. It seems that sometimes we are in a position where we should be able to discover evidence of something, if it indeed existed. For example (using an example by (Larmer, 2002, 131)), if we cannot find a Great Dane in the bathroom even after looking (in other words, there is an absence of evidence of a Great Dane), this is actually good evidence that there is no Great Dane in the bathroom. We simply need to add the premise that we would have discovered evidence of such a mighty hound if it indeed existed. In this way, it might be argued that absence of evidence can actually be evidence of absence, rather than providing merely grounds for a fallacious argument from ignorance. See also (Sober 2009) for discussion about the distinction between absence of evidence and evidence of absence, which is relevant here, as well as (Rhoda 2007) and (Ganssle 2012). D. Walton (2009) analyses the use of this type of argumentation in many fields.

Principles like these have also played a large role in the debate over skeptical theism. Skeptical theists have argued that we are not in a position to evaluate God's reasons for allowing the existence of even horrible evils: the conditions of reasonable epistemic access, CORNEA, have not been satisfied. There has also been debate over "noseeum inferences," of which the Great Dane argument is a good example. If we do not see a Great Dane in the bathroom we can reasonably conclude that it is not there. However, in other cases our inability to detect something does not give us reason to believe that this something does not exist-for example, our inability to see bacteria without instruments does not mean that there are no bacteria in the bathroom. Perhaps God's reasons for allowing evil could be similarly difficult to discern. See (Dougherty 2014b) for further discussion.

Applying all this to the discussion on ID, proponents of ID attempt to argue that we already know enough about biological life and basic chemistry that we can make a decisive conclusion against the possibility of a naturalistic origin of life, or of the possibility of evolving irreducible complexity, for example. They argue that as science progresses, these gaps in naturalistic explanations have only widened, and that we now have a sufficient body of research to be able to conclude something about the limits of natural processes. In contrast, critics of ID argue that we already have evidence that these systems can evolve, and that even if such evidence is lacking, this is to be expected because there has not yet been a sufficient amount of time for research. For some discussion along these lines, see (Behe 2006a, 175-176), (Miller 2002, 147-152), (Dennett \& Plantinga 2011, ch. 2), (Venema 2012) as well as (Jones 2005, 78) and (Behe 2006b, 6-7). See also (Draper 2002) and (Kojonen 2016, ch. 4) for further analysis of the irreducible complexity argument.
} 
238). Haught does not invoke the critique of "arguments from ignorance" against ID, as Dawkins does. Nevertheless, Dawkins would also agree on the substance of this criticism, as would Pennock: ID is invoking design as an explanation for gaps in scientific explanation which we have good reason to believe will ultimately be filled by scientific inquiry. Actually, Dawkins and many other critics of ID argue that many of the "gaps" posited by ID have already been filled by evolutionary explanations, but that proponents of ID have simply not realized this fact. It seems to me that this is a way to rephrase the critique of ID as a God of the gaps that is distinct from the idea of ID as an "argument from ignorance."

Jerry Coyne similarly argues that:

biologists are beginning to provide plausible scenarios for how "irreducibly complex" biochemical pathways might have evolved. As expected, these systems involve using bits co-opted from other pathways originally having different functions. ... In view of our progress in understanding biochemical evolution, it is simply irrational to say that because we do not completely understand how biochemical pathways evolved, we should give up trying and invoke the intelligent designer. If the history of science shows us anything, it is that we get nowhere by labeling our ignorance 'God.' (2005, pt. $\mathrm{V}$ )

Coyne believes that theistic explanations are generally vacuous, but it nevertheless seems to me that Coyne's basic argument can also be appropriated by theists. The argument is that the progress of science can give us good reasons to believe that some particularly scientific mystery will eventually be solved by further scientific inquiry. This then can give us reason to reject ID's argument that these particular mysteries form the likely limit of naturalistic science, and the proper domain of a new kind of design-based science. Instead of claiming that this particular phenomenon is beyond the limits of naturalistic science, it would be more reasonable to wait for further scientific explanations of the phenomenon.

Though there are similarities between the different critiques of GOG here, Haught's critique does differ in an important way from Dawkins and Coyne. Haught is assuming that there is indeed a point where scientific discourse ends and theological discourse begins. This has been formulated in more detail within theological and scientific communities in numerous ways; for example, Arthur Peacocke presents a hierarchical model of the relationship of the different sciences, where each science proceeds by its own method to study those questions which its methods are best suited for analyzing. There can be overlap and connections between the different fields, but by and large each science does its own thing. So, since theology and science work on different levels of explanation, neither needs to be threatened by the other $(1993,217$, fg. 3).

Within the theology and science community, GOG arguments are commonly criticized, but other natural theological arguments, like the fine-tuning argument or the cosmological argument, are often accepted. The concept of limit questions provides one useful point of comparison. Ian G. Barbour defines limit questions as "ontological questions raised by the scientific enterprise as a whole but not answered by the methods of science" $(1997,90)$. However, here I also understand limit questions to include pre-scientific metaphysical questions such 
as the question of the origin of the cosmos and the orderliness of the laws of nature. Theistic arguments based on phenomena which are beyond the limits of science I call limit arguments. One way of arguing the difference between limit arguments and GOG arguments is simply to show that limit arguments are based on phenomena that are clearly disanalogous to the questions normally studied by the natural sciences. The progress of the natural sciences in answering one type of question does not allow us to infer that the natural sciences will also be capable of answering completely different kinds of questions. For example, in his arguments for the existence of God, Richard Swinburne argues based on phenomena that he believes are "too odd" or "too big" for natural science to explain (2004, 74-75).

Based on this, the difference between legitimate limit arguments and illegitimate GOG arguments would be based on our experience and understanding of what kind of explanations work for each type of phenomena. From our experience, we know that the natural sciences are highly fruitful in studying certain kinds of questions, but that other methods are more fruitful in studying other questions. In this understanding, GOG arguments are thought to be problematic because they argue for God based on mysteries where we have reason (based on experience of similar phenomena) that science will ultimately find good solutions. Limit arguments are based on phenomena that our experience shows are vastly different from mysteries that science has been fruitful in solving. These questions may be raised and implied by the natural sciences, but not answered by them.

This way of differentiating between GOG arguments and other theistic arguments seems in principle sound to me, but in practice one runs into problems. Here the difference between the categories is based on the kind of experiences we find ourselves with, as well as the inferences we draw from that experience. This means that different people with a different understanding of what our collective human experience shows may have vastly different views of what counts as a limit argument and what is a God of the gaps. For example, if they were to use these categories, proponents of ID would definitely claim that their design arguments are also limit arguments. This is because according to ID proponents, biology is also "too odd" and "too big" for naturalistic science to explain. They think that biological form and information are beyond the limits of naturalistic science and can be explained only with a new kind of design-based science.

Furthermore, on this account the difference between limit arguments and GOG arguments is contingent, meaning that it is dependent on what kind of world we live in. For example, we can imagine a possible world where the origin of life happens through a natural chemical process, whether deterministic or indeterministic. Most scientists believe that we live in this kind of world. In this possible world, the origin of life does not form a good basis for any limit argument, since it can be studied and explained exhaustively on the level of the natural sciences. However, there is also a possible world where proponents of ID are correct and the origin of life cannot happen through any naturalistic process, but only as an event planned and brought about by an intelligent creator. In this world the origin of life would indeed be the limit of naturalistic biological science. What is called a fallacious GOG argument in one world could be a true limit argument in another world. 
Irrespective of whether we agree with the ID movement's arguments or not, it seems that it is at least possible to imagine a situation where the empirical evidence would count strongly against any naturalistic explanation of the origin of life, for example. Del Ratzsch argues that if we had already done ten thousand years of research on naturalistic origin of life-hypotheses and the difficulties of naturalistic explanations became ever greater with time, we would certainly be in a position to argue that these results tell us something about the inability of natural processes to produce life $(2001,142)$. The idea that we might be able to discover limits to natural processes is also not inherently problematic. In a way all scientific laws also predict something about what will not happen based on what we know about the physical system being examined, not merely about what will happen. For example, we can predict that creating a perpetual motion machine is impossible. Finding out that the origin of life is beyond the capabilities of natural processes might therefore also be in principle possible. ${ }^{8}$

So, how can we tell which kind of world we live in? Do we live in a world where the origin of life is a real limit question, or a problem that is in principle solvable by natural science? I submit again that this can only be decided by experience. That means doing empirical research, and it means that our understanding of the limits and the lack of limits is defeasible. We cannot rule out a priori what sort of arguments for the limits of natural processes are legitimate, but must investigate the soundness of the premises. The origin of life might in principle be a legitimate limit of naturalistic science, as might the origin of irreducible complexity and other such features. This is not to say that this is actually the case in our world-just that it might in principle be. So, if proponents of ID can argue that our evidence shows that the phenomena in question are actual limits of naturalistic science, then it seems that they can avoid this critique of GOG arguments.

One potential objection comes from the differences between ID's arguments and some natural theological arguments, such as the cosmological argument. While something like the Leibnizian cosmological argument is also not totally removed from experience, it depends on much more general features of the world, which could be argued to be true in a wide variety of possible worlds. In the words of Ernan McMullin the doctrine of creation appeals "not to a 'gap' in scientific explanation but to a different order of explanation that leaves scientific explanation intact, that explores the conditions of possibility of there being any kind of scientific explanation" (McMulling 1988, 74). ${ }^{9}$ Some natural theological arguments that work on this kind of broad and metaphysical level do seem to be very different from the ID's movement's design arguments. For example, the

\footnotetext{
${ }^{8}$ Related to this, John C. Lennox $(2007,188-192)$ makes the interesting distinction between two types of gaps in natural science. First, there are "gaps of ignorance," where our inability to explain something by reference to physical processes is merely a product of our ignorance. But there are also "gaps in principle" which are a product of what we do know, and are only deepened as we come to further understand science. Lennox gives the example of meaningful writing: no matter how much we study the physics and chemistry of paper and ink, we will not find reductionist explanation which will help us explain writing without design. Some reductionists will disagree with Lennox, but currently this does seem to be a reasonable position. See (Horst 2012) for a critique of reductionism. Russell $(2008,126-127 ; 2006,584)$ similarly distinguishes between epistemic and ontological gaps in the capabilities of natural processes. ${ }^{9}$ Similarly, Polkinghorne (2006) argues that natural theology does not compete with the natural sciences, but builds on their success to explain why natural science is possible in the first place.
} 
traditional question "Why is there something rather than nothing?" does not seem liable to be ever answered by natural science (though some, such as Lawrence Krauss, have recently argued that even this question has been answered by natural science) ((Krauss 2012), for critique see (Albert 2012)). In contrast, ID's design arguments, such as the argument from irreducible complexity, depend on very specific, even minute features of the biological world. They can at least be overturned by further scientific progress, if they haven't been already falsified. We can imagine a world where evolutionary explanations for information and irreducible complexity work without needing to invoke the actions of a designer working beyond the laws of nature. But imagining a contingent world that does not depend on a necessarily existing being seems at least much more difficult, if not impossible.

A natural theologian sticking merely to metaphysics can therefore argue that even if ID's understanding of the limits of naturalistic explanation in biology were correct, there would still be a qualitative difference between ID's biological design argument and arguments like the Leibnizian cosmological argument. However, other commonly used natural theological arguments do also make use of more specific features of the world, which are not shared by all possible worlds. For example, the fine-tuning argument refers to the precise properties of the laws of constants of nature, and arguments from religious experience and miracles refer to particular religious experiences and particular historical accounts of miracles (Craig \& Moreland, 2010). These are not arguments that could be made in any possible world, yet they are not (usually) considered examples of God of the gaps arguments. At least these arguments are often considered plausible, even if they are different from the traditional metaphysical arguments. And if they are also admitted as legitimate natural theological arguments rather than GOG arguments, then the border between limit arguments and GOG arguments again becomes somewhat vague and porous.

Though the distinction between GOG arguments and limit arguments may be clear in principle, in practice we may find ourselves with different ideas of which argument is a GOG argument and which is not. Again, different people will have different ideas about what the evidence is, and what our collective human experience actually demonstrates about the limits of science. We may find ourselves uncertain about the limits of science, and because of this, I submit that we should think of our assessments of different arguments as moving on a continuum between limit questions and gaps arguments. Our experience of what kind of phenomena the natural sciences have previously been successful in studying is the best guide here. In cases closely analogous to such previously solved problems, we will have strong inductive grounds for believing that the natural sciences will ultimately solve this new case as well. But we have much less inductive support for believing that the natural sciences will eventually solve cases that are strongly disanalogous to those they have previously solved. Problems that we cannot even dream of studying through scientific methods would most easily be classified as good bases for limit arguments.

Even where we might in principle be able to study some phenomenon scientifically, such as in the case of the origin of life, the progress of science might in principle be able to change our perspective. The origin of life might in time begin to look more and more like a problem that is totally disanalogous to any other problem that has been solved through the methods of the natural sciences, and so 
we might be more inclined to think that this problem is better studied with methods of design detection. We might even start to think that the origin of life is the proper boundary between theology and the natural sciences. So, just where each argument will fit on the continuum will depend on how strong we think the premises of each argument are, and how analogous we think the issue is with questions that have been successfully explained by using methodologically naturalistic scientific methods. In other words, how we place each argument on the continuum will depend on how likely we think the argument is to be defeated by further experience.

Comparing limit arguments and GOG-arguments on a continuum

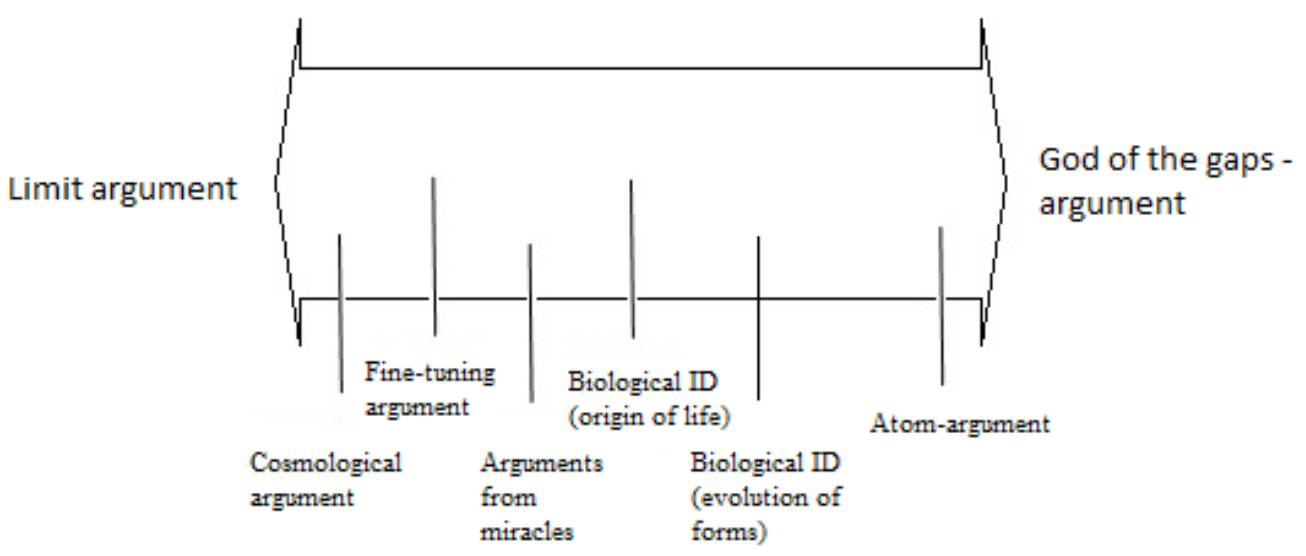

In this figure, I have placed the different arguments on the continuum somewhat arbitrarily simply to explain the general idea of the continuum. Where we place each argument will depend on our current estimate of its supporting evidence. For example, an ID proponent might place ID's biological design arguments at about the same point as fine-tuning, whereas someone holding the belief that all of reality will ultimately be explainable through scientific methods would place all of the arguments on the God-of-the-gaps side. Some will even even reject the legitimacy of those questions which would still remain outside the province of the natural sciences, such as the question "Why is there something rather than nothing?", which underlies Leibnizian cosmological arguments. ${ }^{10}$

It seems to me that ID's critics do not need to question the in-principle possibility of arguing that natural processes have limits. It also doesn't need to be argued that ID's arguments are logical fallacies of a God-of-the-gaps type, because it seems that such an argument could work in principle. Rather, the crucial question is whether we have enough knowledge to conclude that the present existence of mysteries in cosmology and biology gives enough reason to conclude that at least some of these mysteries will remain unsolved using the methods of science, and if the data supports ID's contention that these phenomena are better explained by methods that are more analogous to those used in detecting human design, rather than the traditional methods of physics and biology. This, in my

\footnotetext{
${ }^{10}$ Ironically, this rejection of all theistic explanations as instances of the "God of the gaps" might even be called an "atheism of the gaps" (Alexander, 2009) or a "naturalism of the gaps," since it assumes (perhaps without adequate basis in experience) that the solution of any and all mysteries will be naturalistic.
} 
view, is ultimately the core of the disagreement between proponents of ID's biological design arguments and their critics. ${ }^{11}$ However, in this way of framing the argument the identification of ID as a God of the gaps is only the conclusion of our evaluation of the argument. It does not form the basis of our critique of ID, as it often does, particularly on the popular level. Another interesting conclusion also follows from this for the popular use of the God of the gaps-critique against all theistic argumentation: if this critique cannot rule out biological ID a priori, then it can be used even less to rule out other theistic arguments a priori, since these usually depend less on specific empirical details than ID does.

If the purpose of the critique of GOG arguments is to dialogue with proponents of ID or persons undecided about the merits of ID's arguments, then it would be better to simply state that one finds some of the core premises of ID's arguments weak, and to be very specific about the problems with these premises. Doing so would result in fewer misunderstandings. This is because ultimately the distinction between limit arguments and GOG arguments comes quite close to the distinction between arguments we find plausible and arguments we find implausible. However, perhaps the primary purpose of deeming ID a GOG argument is not to dialogue with ID proponents. Perhaps this critique is more about building the credibility of theistic natural theological argumentation for those who reject the plausibility of ID's argumentation. The point of the critique would then be simply to build distance between mainstream natural theology and ID, and to show that theologians also reject arguing for God based on phenomena that are better explored through the natural sciences. In this case the differentiation between limit arguments and GOG arguments can still have value.

\section{Theological Concerns}

In addition to philosophical critiques of GOG arguments, two theological critiques of the arguments have also been important. First, (1) such arguments are thought to present a misleading understanding of God that does not respect the full breadth of the doctrine of creation, and second (2) gaps arguments are claimed to be apologetically dangerous: if faith in God is based on the existence of gaps, then the progress of science in closing these gaps will tend to undermine faith. I will now turn to these issues.

Though the critique of the God of the gaps often takes a philosophical form, and has also been used by atheists, the term does have theological origins. In English, the first use of the terminology of GOG-critiques that I know of comes from Scottish evangelist Henry Drummond (1851-1897), who asked: "There are reverent minds who ceaselessly scan the fields of Nature and the books of Science in search of gaps-gaps which they will fill up with God. As if God lived in gaps?" (Drummond 2008 [1883], 166). The phrase "God of the gaps" was subsequently adopted by many Christian theologians and natural scientists looking for a theology in harmony with the natural sciences.

\footnotetext{
${ }^{11}$ Proponents of ID and proponents of theistic evolution also have other core differences, such as a different understanding of the compatibility of theism and evolution. I have analysed and criticized ID's arguments against theistic evolutionism in more detail in (Kojonen 2013).
} 
In criticizing GOG arguments, Robert J. Russell echoes the basic point that gaps arguments problematically locate God's activity primarily in interventions into the natural order, rather than realizing God's presence in the regularities of nature as well: "The problem with interventionism is that it suggests that God is normally absent from the web of natural processes, acting only in the gaps that God causes" (2006, 584).12 In theological and scientific communities, there is much desire to avoid this kind of God of the gaps. The discussion is also related to the broader discussion on miracles understood as "interventions" or alternatively simply as events that go beyond the capacities of natural processes. ${ }^{13}$ Some who have this concern about the God of the gaps formulate an understanding of divine action in which miracles have no place. Others are concerned more with the overt emphasis on miraculous divine action over general divine providence and noninterventionist divine action. ${ }^{14}$

Reminders of the breadth of divine action and the breadth of the doctrine of creation may also be useful for the discussion of ID. While proponents of ID do also affirm general divine providence, in practice some of their argumentsparticularly against theistic evolution-do seem to make the rationality of belief in creation depend on the existence of gaps in nature. For example, Dembski writes that:

within theistic evolution, God is a master of stealth who constantly eludes our best efforts to detect him empirically. Yes, the theistic evolutionist believes that the universe is designed. Yet insofar as there is design in the universe, it is design we recognize strictly through the eyes of faith. Accordingly the physical world in itself provides no evidence that life is designed. For all we can tell, our appearance on planet Earth is an accident. $(1999,110)$

Dembski may not mean what he says here, since surely he is aware of theistic natural theology, and the fact that many theistic evolutionists consider fine-tuning as evidence of design. However, the quote is indicative of a broader tendency within the ID movement to emphasize the great importance of biological evidence of design for the defence of belief in creation. Phillip E. Johnson similarly argues that:

\footnotetext{
12 Similarly (Russell 2008, 126-127) and (Bube 1994, 60). Russell's main motivation in the quoted section is not to dismiss God's ability to act in the world, but to motivate the need for his proposal of noninterventionistic divine action, in which God can act in the world through quantum events without breaking through natural regularities. For further discussion on noninterventionist divine action, see (Russell 2009), which reviews the massive divine action project jointly organized by the Center for Theology and the Natural Sciences (California, Berkeley) and the Vatican Observatory.

13 On this discussion, see Kojonen (forthcoming). See also (McGrew 2013) for a discussion on different concepts of miracles and (Carroll 2010) for a discussion of different understandings of "natural laws."

${ }^{14}$ I am content to use the old, somewhat simplistic distinction between general and special divine providence in this section, since here the question is simply if God acts in the world in a way that goes beyond general providence. For a more nuanced categorisation of different types of divine action, see (Tracy 2006). For a further critique of the distinction between general and special divine action, see e.g., (Gregersen 2009). On the problem on natural evil related to the evolutionary process, see (Dougherty 2014a) and (Murray 2011). For an insightful paper relating the problem directly to the ID debate, see (Corabi 2009).
} 
If God stayed in that realm beyond the reach of scientific investigation, and allowed an apparently blind materialistic evolutionary process to do all the work of creation, then it would have to be said that God furnished us with a world of excuses for unbelief and idolatry. (1993b)

Given this strong emphasis on the theological importance of biological design arguments, the warning against the God-of-the-gaps can serve to remind us of the breadth of the doctrine of creation and its metaphysical nature. Its credibility need not depend on finding gaps in the abilities of naturalistic evolutionary processes.

Nevertheless, it is also possible to defend a biological design argument without limiting divine activity merely to gaps. Though some have posited a contradiction between believing in general divine providence and miracles, such a contradiction is not usually posited by those making miracle claims themselves. Indeed, the historic Christian position also recognized both general and special divine providence, including miracles (Larmer 2002 \& 2015). Proponents of ID also defend the fine-tuning argument, thus recognizing the Creator also in the regularities of nature. Even regarding evolution, they are prepared to accept that God could have directed evolution through natural processes, but argue simply that such direction is contrary to the mainstream Neo-Darwinian understanding of evolution. Proponents of ID might be willing to accept a different kind of theory of evolution, however. I have analysed ID's relation to theistic evolution more closely elsewhere (Kojonen 2013). ${ }^{15}$

There are many different models of divine action, and it is possible to formulate a theological view that rejects all divine interventions, or at least all divine interventions within natural history, if not within salvation history. For example, on the metaphor that the world is like machine created by the divine artificer, it seems odd to think that the artificer would have to repair the machine after its creation. On this metaphor the existence of gaps in nature might actually be evidence against the existence of God, rather than evidence for God, since we would expect God to be perfect in his craftsmanship, so that there would be no need to tinker with his creation. However, on the metaphor of the world as God's kingdom or temple, it becomes much more credible that God would also act in the universe beyond the laws of nature. One would expect a perfect king to have a personal interest in his domain and subjects, acting to influence the development of his kingdom in a positive direction. ${ }^{16}$

There is much room for further theological exploration of these different models, and for arguments about which model is superior theologically. Strong theological arguments could influence what the Christian would expect a priori

\footnotetext{
${ }^{15}$ See also (Kojonen 2016, ch. 10). On ID and fine-tuning see also (Kojonen 2016, ch. 5). For one recent formulation of a model of divine action allowing both general providence and special divine action in miracles and ID, see (Larmer 2014, ch. 1). Rusbult (2004) provides a more complete description of the possibilities with seven different types of gap-theologies. ${ }^{16}$ Along these lines, Dembski $(2002,327-328)$ uses the metaphor of the world as a musical instrument to defend the possibility of the creator interacting with the world. See also the discussion of different metaphors of the God-world relationship in relation to the ID debate by (Murray 2003 and 2006). Dembski, Downes \& Frederick ed. (2008) is a collection of writings from the Church Fathers collected by proponents of ID for the purpose of exploring metaphors which might fit with ID better than the machine metaphor.
} 
about the limits of the natural sciences. However, though this paper does not allow for a thorough exploration of the matter, I submit that the theological arguments we do have are not really decisive on this issue. Historically Christian has allowed for both general and special divine providence, even including miracles. On this historical understanding, it is difficult to rule out things like ID's biological design arguments theologically. For example, God could have created life through a supernatural miracle, which would be compatible with the ID position. On the other hand, if we accept God's ability to also act through natural processes, as traditional Christian theology does, then we also cannot rule out a priori the possibility that God could have used natural processes to create life. So, it seems to me that Christian theology is flexible enough to be compatible both with ID and with theistic evolution. We could argue for or against either possibility based on the empirical evidence we have. ${ }^{17}$

Another, related theological concern is about the model of divine action presupposed by ID's biological design arguments. According to some interpreters, in this argument the Creator appears to work on the same level as the processes investigated by the natural sciences. This then seems like ID is confusing primary and secondary causes. For example, theologian Conor Cunningham argues that the designer that ID would prove would not be worthy of worship, "because it would merely be a domesticated god, a 'natural' god. This God might have bigger biceps, a Jedi Knight of sorts. He might be merely Homeric, but he certainly would not be Abrahamic" (2010, 278). This is because, Cunningham argues, the kind of argument where God acts on the same level as natural causes cannot prove the God who is the ground of all contingent reality, not merely a part of it.

I believe that Cunningham is correct that ID does not speak of this aspect of the doctrine of creation, and thus provides at best an incomplete defense of belief in the doctrine. But one problem with this critique is that ID is not attempting to exhaustively describe the Creator. This is already implicit in ID's differentiation between the designer and identifying the designer as God: If God were not more than a designer in ID's understanding, then this kind of strong differentiation should not be possible. The implied understanding is that God is more than a designer, but also not less than a designer. This is in line with fairly common descriptions of theological language: our language fails not because it says too much of God, but because it says too little. No natural theological argument can describe the full breadth of the Creator, and theologians generally believe that all mystery about the Creator cannot be eliminated anyway. Proponents of ID can appeal to the same kind of arguments to defend their use of the language of "design" about the Creator. ${ }^{18}$

\footnotetext{
17 This is in line with what theologian Colin Gunton calls "the order of knowing" (Gunton 2002, 97). According to Gunton, in theology we should infer the divine nature based on God's acts, such as the incarnation. Applying this to the ID debate, one might argue that we should infer how God acts in nature based on what the evidence seems to support. If ID's arguments succeed, then that should influence our beliefs about how God acts, if they fail, then theistic evolutionism seems more plausible. Gunton is also relevant for the debate otherwise. Quoting Gunton, Sollereder uses the doctrine of the Incarnation to argue that God can indeed act in the world on the level of causes: "In comparison to the indignity of Jesus' death, the indignity suffered by God in acting as a cause among causes can hardly count as scandal" $(2015,349)$.

18 On the related discussion concerning "onto-theology," see (Turner 2004) as well as (McCord Adams 2014).
} 
Though ID fails to describe the full depth of the doctrine of creation, there is also commonality with the doctrine of God as Creator of the order of the nature. In studies of the historical development of the doctrine of creation, it is often even argued that the idea of God as the conqueror of the forces of chaos and the creator of order in the cosmos preceded the doctrine of creatio ex nihilo and metaphysical developments of the doctrine. As McGrath points out, "the theme of ordering is of major importance to Old Testament conceptions of creation" $(2001,155) .{ }^{19}$ The fact of existence is not the only thing explained by the doctrine of creation; it also seeks to explain the rationality and beauty of the world God has created. It is with this part of the doctrine of creation that ID's "designer" who purposefully creates order can find consonance. ${ }^{20}$ Furthermore, though the Creator should not be confused with secondary causes, this does not mean that the Creator would not have the ability to create the effects of secondary causes. Here Aquinas agrees, but argues that when God miraculously creates such effects, he is doing so as a primary cause. I do not see why proponents of ID could not defend their arguments in a similar way. ${ }^{21}$

\section{Apologetic Concerns}

The second theological concern with God of the gaps arguments is apologetic: if belief in God is primarily based on gaps in scientific explanations, then the progress of the natural sciences in filling these gaps will tend to undermine belief in God (Brooke 2010, 78-79). Dietrich Bonhoeffer famously argues in a letter written while imprisoned by the Nazis in Tengel in 1944 that:

it is wrong to use God as a stopgap for the incompleteness of our knowledge. If in fact the frontiers of knowledge are being pushed further and further back (and that is bound to be the case), then God is being pushed back with them, and is therefore continually in retreat. We are to find God in what we know, not in what we do not know; God wants us to realize his presence, not in unsolved problems but in those that are solved. (Bonhoeffer 1997, 311)

This critique is linked to the earlier critique of GOG arguments as arguments based on phenomena that are likely to be explained by the further progress of the natural sciences. Based on the history of science, many argue that it is better to present evidence of God based on phenomena which are not expected to ever be open to scientific study (that is, limit arguments rather than GOG arguments). Kenneth Miller sums up the feelings of many:

\footnotetext{
19 See further (J. Walton 2009).

20 This is not to say that all versions of the doctrine of creation will be compatible with ID. For example, from the standpoint of process theology, a creator ordering nature could be seen as coercion and contrary to love (Oord 2010).

${ }^{21}$ On Aquinas' position, see (Silva 2014, 13-14) and (Sollereder 2015). Silva is discussing Alvin Plantinga's (2011) arguments on miracles, which I am broadly agreeing with here. I discuss Plantinga further in Kojonen (forthcoming).
} 
I find it puzzling and disappointing that so many would have pinned their religious hopes on the inability of science to explain the natural world. ... [A]n accurate and complete understanding of that world, even in purely material terms, should deepen and strengthen the faith of any religious person. (Miller 2002, 169)

The theological critique of the God of the gaps is meant to guard against the temptation to forget the broad grounds of faith. ${ }^{22}$

Though pastoral concerns are important for doing theology, the pastoral and practical nature of this critique does have two consequences. First, these pastoral arguments, if taken in isolation, are about the practical consequences and usefulness of gaps arguments, rather than their validity and force. Furthermore, these concerns are related to the attitudes of those making the arguments, rather than the validity of the arguments themselves.

Because the concerns are not related to any necessary features of the arguments as such, there does not seem to be any reason why someone could not defend an argument for divine action beyond the laws of nature while at the same time admitting that the grounds of faith lie elsewhere. For example, a Catholic Christian might defend the veracity of the healings that are believed to have happened in response to the intercession of Pope John Paul II, and these are seen as proofs of his sainthood. However, the Catholic faith has much broader grounds, and wouldn't be threatened even if these particular healings were proven to be forgeries.

Similarly, I do not see a reason why someone could not defend something like a biological design argument without making the rationality of religious faith depend on it. Let's say someone has no theological objection to the origin of life being an event that can be explained purely in terms of chemistry, with no need for divine intervention. Suppose further that this person knows all the usual stuff about the nature of religious faith and the broad basis of religious belief, so that his faith is not at all insecure. But suppose this person just finds the origin of life highly disanaloguous to any event that can actually be explained through naturalistic science. Let us also assume that this person finds the biological design argument convincing, though he or she has theological need for such arguments. This person would then be an advocate of a biological design argument without making his/her faith depend on it. Adopting this kind of attitude would seem to avoid the pastoral problem with gaps arguments, and I would recommend it to proponents of ID. ${ }^{23}$

The second point that follows from the pastoral and practical nature of this critique is that other practical considerations might also enter into play, and someone might make a different risk/reward assessment of the situation. Thomas Aquinas argued that "by no other means can it better be made manifest that all nature is subject to the divine will, than by the fact that He sometimes works independently of the order of nature" (Summa Contra Gentiles, bk. 3, ch. 99). ${ }^{24}$

\footnotetext{
22 See also (Harvey 2000).

${ }^{23}$ Actually the situation here is not too different from how natural theologians typically present their arguments, or from arguments in general. All arguments are defeasible, not just GOG arguments. But the defeasibility of arguments does not imply that we should give up making them.

24 Translation from (Aquinas 1997, 197).
} 
Ross McCullough applies this to the contemporary debate and argues that apologetic concerns might also lead us to support a gaps-argument. McCullough argues that if a gaps-argument for a miracle in human history or natural history was successful, it would serve as powerful evidence against any naturalistic worldview (2013). In addition to possible payoffs for a successful gaps-argument, one might attempt to minimize the risks in some way. For example, if one recognizes that religious faith has broad grounds, then one might present a gapsargument provisionally, without basing one's entire faith on the success of one particular argument. Because of the possibility of such responses, the pastoral critique does not seem to be decisive in blocking GOG arguments, though it does serve as a useful warning against a narrow dependence on such arguments.

As with the previous critiques of gaps arguments, I submit that our proper response to the pastoral concern should also depend on what we think about the evidence. We will have to ask if we can honestly say that we are in a position to make an informed assessment that the proposed gap really provides grounds for a limit argument, rather than a GOG argument. If it looks like the progress of science is likely to close some particular gap, then it will seem like an extremely risky strategy to advocate an argument based on this event. On the other hand, if some phenomenon looks like a genuine limit of science, and if we also have robust broader grounds for our faith, then there is much less need to be afraid of a limit argument being proven wrong.

Ultimately, if we reject ID's biological design arguments, then it should be because we find some premise of these arguments improbable, not because they fit a class which we can label "God-of-the-gaps" based on some a priori criteria. ${ }^{25}$ Theists can follow the evidence in deciding whether and what sort of "gaps" there are in nature. Thus theistic evolutionist Keith Ward can also argue "if there is a God, a Creator of the universe, it is plainly possible that God might perform miracles, might bring about events that no created cause has the power of itself to bring about" $(2002,742)$. Acceptance of biological ID in principle as something that could be true in some possible world that God could create does not logically require accepting that such a divine intervention has actually happened in our world. But it does mean that the apologetic concern over the possible effects of GOG arguments is not a decisive reason for rejecting such arguments, but merely a reason to situate such arguments in the broader context of the Christian faith and to be humble in making arguments about limits.

The theological critiques are also aimed at promoting the harmony of theology and science. Theological and scientific explanations generally work on different levels, and do not need to be in conflict with one another. This observation can still be apologetically useful in view of the frequent opposition of evolution and creation on the popular level. However, this basic point can be made without critiquing the God-of-the-gaps argument.

\footnotetext{
${ }^{25}$ In other words: apologetic concerns will count against ID's design arguments only if these arguments have already been revealed to be philosophically and scientifically weak. But if that weakness has already been shown, then proponents of ID already have good reason to give up their arguments even without considering these additional apologetic concerns.
} 


\section{Conclusion}

Critique of God-of-the-gaps arguments takes many forms. Based on my analysis, the most legitimate of these critiques is to denote arguments in which theological explanations are used at a point where it would be more reasonable to wait for a scientific explanation. However, the boundary between God-of-the-gaps arguments and limit questions is fluid and changes based on what the evidence shows. Since people have different ideas of the state of the evidence supporting each argument, we will also have different ideas of where the boundaries are. Proponents of ID are unlikely to reject their arguments simply because others call these GOG arguments, since identifying a particular argument as a God-of-thegaps argument requires showing that its premises are weak, and proponents of ID believe that the premises of their arguments are strong. However, differentiating between God-of-the-gaps arguments and limit arguments may still be useful for defending the possibility of at least some natural theological discourse for those who reject ID.

The validity of theological critiques of gaps arguments also depends on first assessing the premises of the argument and showing that they are weak. It is possible for someone to defend gaps arguments because they think that the possibility of religious faith in God depends on such arguments and do not understand the broad nature of the grounds of religious faith. In such a case the critique of God-of-the-gaps arguments can function as a reminder that religious faith should not depend on the failure of the natural sciences to understand phenomena that are within the domain of the natural sciences. However, it is also in principle possible to defend gaps arguments while simultaneously recognizing that faith has much broader grounds, and God also acts in the laws and processes of nature. It is similarly in principle also possible for someone to have reasonable grounds for believing that a particular gap in present explanations will not be filled by future scientific inquiry. Theological critiques of God-of-the-gaps arguments can perhaps be helpful for reminding theistic natural theologians and proponents of ID to be humble in their defense of arguments that depend on highly specific empirical details. However, the theological critiques of God-of-the-gaps arguments that I have analysed here do not themselves function as rebuttals of the premises of these arguments.

Though I have defended the in-principle possibility of finding limits to natural explanations, the point of this paper is not to endorse any particular argument about limit questions or gaps, whether fine-tuning, the miracle of the resurrection, the miracles of the saints, or the intelligent design of the first living cell. I have merely been arguing that the issues in rejecting gaps arguments are complex, and deeming an argument God-of-the-gaps does not provide us with any philosophical or theological principle that could by itself solve the debate over complex arguments like Intelligent Design. ${ }^{26}$

\footnotetext{
${ }^{26}$ This paper was first presented as part of the Oxford-Helsinki Analytic Theology workshop at the University of Helsinki, Faculty of Theology in January 2015. I wish to thank participants of the workshop for excellent discussion and helpful feedback on the paper, as well as my many other dialogue partners. I also wish to thank the anonymous referee of this paper for providing detailed and constructive feedback which helped make the paper's arguments much clearer.
} 
Bibliography

Albert, David. 2012. “On the Origin of Everything. 'A Universe From Nothing,' by Lawrence M. Krauss." The New York Times, Sunday Book Review, March 23. Available at <http://www.nytimes.com/2012/03/25/books/review/auniverse-from-nothing-by-lawrence-m-krauss.html>. Accessed on September 23, 2015.

Alexander, Denis. 2009, "Evolution, Intelligent and Designed." Intelligent Faith: A Celebration of 150 Years of Darwinian Evolution. Ed. John Quenby \& John MacDonald Smith. 0 Books. 7-22.

Aquinas, Thomas. 1997. Basic Writings of Saint Thomas Aquinas. Volume Two: Man and the Conduct of Life. Ed. Anton. C. Pegis. Hackett Publishing.

Barbour 1997, 90. Religion and Science: Historical and Contemporary Issues. A Revised and Expanded Edition. HarperOne.

Behe, Michael J. 2006a. Darwin's Black Box. 10 ${ }^{\text {th }}$ Anniversary Edition. The Free Press.

. 2006b. "Whether Intelligent Design is Science: A Response to the Opinion of the Court in Kitzmiller v Dover Area School District." Discovery Institute. February 3. Available at <http://www.discovery.org/f/697>. Accessed on September 23, 2015.

Bonhoeffer, Dietrich. 1997. Letters and Papers from Prison. New Greatly Enlarged Edition. Touchstone.

Brooke, John Hedley. 2010. "Learning from the Past." God, Humanity and the Cosmos. Second Edition, Revised and Expanded as A Companion to the Science - Religion Debate. Ed. Christopher Southgate. T \& T Clark International. 63-81.

Bube, Richard H. 1994. Putting it All Together: Seven Patterns for Relating Science and the Christian Faith. University Press of America.

Carroll, John W. 2010. "Laws of Nature.” The Stanford Encyclopedia of Philosophy. Spring 2012 Edition. Ed. Edward N. Zalta Available at <http://plato.stanford.edu/archives/spr2012/entries/laws-of-nature/>.

Chick, Jack T. 1991 (1972). Big Daddy? Chick Publications.

Comfort, Nathaniel C. (Ed.) 2007. The Panda's Black Box: Opening up the Intelligent Design Controversy. The Johns Hopkins University Press.

Copi, Irving M. \& Cohen, Carl. 1990. Introduction to Logic. Macmillan. 
Corabi, Joseph. 2009.“Intelligent Design and Theodicy." Religious Studies. Vol. 45. No. 1. 21-35.

Coulson, Charles A. 1958. Science and the Idea of God. Cambridge University Press.

Coyne, Jerry. 2005. “The Case Against Intelligent Design.” Edge.org. Wed. Nov. 13. Available at <http://www.edge.org/conversation/the-case-againstintelligent-design>. Accessed on January 24, 2014.

Craig, William \& Moreland, J.P. (Eds). 2010. The Blackwell Companion to Natural Theology. Blackwell Publishing.

Dawes, Gregory A. 2007 'What is Wrong with Intelligent Design?' International Journal for Philosophy of Religion. Vol. 61. No. 2. 69-81.

Dawkins, Richard. 2006. The God Delusion. Bantam Press. 1991. The Blind Watchmaker: How the Evidence of Evolution Reveals a Universe without Design. Penguin.

De Cruz, Helen and De Smedt, Johan. 2015. A Natural History of Natural Theology: The Cognitive Science of Theology and Philosophy of Religion. The MIT Press.

Dembski, William A. 1998. The Design Inference: Eliminating Chance through Small Probabilities. Cambridge Studies in Probability, Induction and Decision Theory. Cambridge University Press.

1999. Intelligent Design: The Bridge Between Science and Theology. InterVarsity Press.

2002. No Free Lunch: Why Specified Complexity Cannot Be Purchased Without Intelligence. Rowman \& Littlefield Publishers.

Dembski, William A. \& Ruse, Michael (Eds.) 2004. Debating Design: From Darwin to DNA. Cambridge University Press.

Dennett, Daniel \& Plantinga, Alvin. 2011. Science and Religion: Are They Compatible? Oxford University Press.

Dougherty, Trent. 2014a. The Problem of Animal Pain. Palgrave McMillan. . 2014b. "Skeptical Theism". The Stanford Encyclopedia of Philosophy (Spring 2014 Edition). Ed. Edward N. Zalta. Available at <http://plato.stanford.edu/archives/spr2014/entries/skepticaltheism/>. Accessed on November 3, 2015. 
Draper, Paul. 2002. "Irreducible Complexity and Darwinian Gradualism: A Reply to Michael Behe." Faith and Philosophy. Vol. 19. No. 1. 3-21.

Drummond, Henry. 2008 [1883]. The Lowell Lectures on the Ascent of Man. Wilder Publications.

Ganssle, Gregory. 2012. “'God of the Gaps' Arguments.” The Blackwell Companion to Science and Christianity. Ed. Stump J. B. \& Padgett, Alan G. Oxford: Blackwell. 130-139.

Glass, David H. 2012. “Darwin, Design and Dawkins' Dilemma.” Sophia. Vol. 51. No. 1. 31-57.

Gliboff, Sander. 2000. "Paley's Design Argument as an Inference to the Best Explanation, or Dawkins' Dilemma." Studies in the History and Philosophy of Biological and Biomedical Sciences. Vol. 31. No. 4. 579-597.

Gonzales, Guillermo and Richards, Jay. 2005. The Privileged Planet: How our Place in the Cosmos is Designed for Discovery. Regnery Publishing.

Gregersen, Niels. 2009. "Special Divine Action and the Quilt of Laws: Why the Distinction Between Special and General Divine Action Cannot be Maintained." Scientific Perspectives on Divine Action: Twenty Years of Challenges and Progress. Ed. Robert J. Russell, Nancey Murphy \& William R. Stoeger. CTNS. 179-199.

Tracy, Thomas F. 2006. "Theologies of Divine Action." The Oxford Handbook of Religion and Science. Ed. Phillip Clayton. Oxford University Press. 596-611.

Gunton, Colin. 2002. Act and Being. SCM Press.

Harvey, Alan. 2000. "What Does God of the Gaps Mean?” Allen Harvey's Homepage. Available at <http://steamdoc.s5.com/writings/gaps.html>. Accessed on December 11, 2013.

Haught, John F. 2004. "Darwin, Design and Divine Providence." Debating Design: From Darwin to DNA. Eds. William A. Dembski \& Michael Ruse. Cambridge University Press. 229-244.

Haught, John F. 2008. "Is Fine-Tuning Remarkable?" Fitness of the Cosmos for Life: Biochemistry and Fine-Tuning. Eds. John Barrow, Simon Conway-Morris, Stephen Freeland \& Charles Harper. Cambridge University Press. 31-48.

Horst, Steven A. 2012. Beyond Reduction: Philosophy of Mind and PostReductionist Philosophy of Science. Oxford University Press.

Johnson, Phillip E. 1993a. Darwin on Trial. 2nd ed. IVP. 
1993b. 'Creator or Blind Watchmaker?' First Things. January Issue. Available at <http://www.firstthings.com/article/1993/01/001-creatoror-blind-watchmaker>. Accessed on November 2, 2015.

Jones, John E. 2005. Tammy Kitzmiller,et al. v. Dover Area School District, et al. Memorandum Opinion. Case 4:04-cv-02688-JEJ. Document 342. The United States Disctrict Court for the Middle State of Pennsylvania. Available at $<$ https://www.aclu.org/sites/default/files/field_document/asset_upload_ file577_23137.pdf'>. Accessed on September 23, 2015.

Kojonen, Erkki V. R. 2013. "Tensions in Intelligent Design's Critique of Theistic Evolutionism." Zygon, vol. 48 no. 2, 251-273.

2016. The Intelligent Design Debate and the Temptation of Scientism. Routledge.

. Forthcoming. "Is Classical Science in Conflict with Belief in Miracles? Some Bridge-Building Between Different Positions." God's Providence and Randomness in Nature: Scientific and Theological Perspectives. Ed. Robert John Russell and Joshua M. Moritz. (West Conshohocken: Templeton Press, 2017).

Koperski, Jeffrey. 2015. The Physics of Theism. Wiley-Blackwell.

Krauss, Lawrence M. 2012. A Universe from Nothing: Why There is Something Rather than Nothing. The Free Press.

Larmer, Robert. 2002. "Is There Anything Wrong with 'God-of-the-Gaps' Reasoning?" International Journal for Philosophy of Religion. Vol 52. No. 3. 129-142.

2014. The Legitimacy of Miracle. Lexington Books.

Lennox, John C. 2007. God's Undertaker: Has Science Buried God? Lion.

McCord Adams, Marilyn. 2014. "What's Wrong with the Ontotheological Error?" Journal of Analytic Theology. Vol. 2. 10.12978/jat.2014-1.120013000318a.

McCullough, Ross. 2013. "God and the Gaps." First Things. April Issue. Available at <http://www.firstthings.com/article/2013/04/god-and-the-gaps>. Accessed on September 23, 2015.

McGrath, Alister. 2009. Darwinism and the Divine: Evolutionary Thought and Natural Theology. Wiley-Blackwell.

McGrew, Timothy. 2013. "Miracles." Stanford Encyclopedia of Philosophy. Spring 2013 Edition. Ed. Edward N. Zalta. Available at <http://plato.stanford.edu/archives/spr2013/entries/miracles/>. 
McMullin, Ernan. 1988. "Natural Science and Belief in a Creator: Historical Notes." Physics, Philosophy, and Theology: A Common Quest for Understanding. Ed. Robert J. Russell, William R. Stoeger \& George Coyne. Vatican Observatory Press.

Meyer, Stephen C. 2013. Darwin's Doubt: The Explosive Origin of Animal Life and the Case for Intelligent Design. HarperCollins.

Moore, Randy; Decker, Mark D. (2008). More than Darwin: an Encyclopedia of the People and Places of the Evolution-Creationism Controversy. Greenwood Press. p. 56.

Miller, Kenneth. 2002. Finding Darwin's God: A Scientist's Search for Common Ground Between God and Evolution. Harper Perennial.

Murray, Michael J. 2011. Nature Red in Tooth and Claw: Theism and the Problem of Animal Suffering. Oxford University Press.

2003 'Natural Providence (or Design Trouble)?' Faith and Philosophy. Volume 20. Issue 3. 307-327.

2006 'Natural Providence: Reply to Dembski'. Faith and Philosophy. Vol. 23. No. 3. 337-341.

Oord, Thomas Jay. 2010. "A Theologian Evaluates Intelligent Design." Thomas Jay Oord's Blog. Available at $<$ http://thomasjayoord.com/index.php/blog/archives/a_theologian_eval uates_intelligent_design_pt._1_of_3/>. Accessed on January 22, 2014.

Peacocke, Arthur. 1993. Theology for a Scientific Age: Being and Becoming, Divine and Human. Enlarged edition. Fortress Press.

Pennock, Robert. 2007. "The God of the Gaps: The Argument from Ignorance and the Limits of Methodological Naturalism." Scientists Confront Creationism: Intelligent Design and Beyond. Eds. Andrew J. Petto \& Laurie R. Godfrey. New York, NY: W.W. Norton \& Co. 309-338.

Pennock, Robert (Ed). 2001. Intelligent Design Creationism and Its Critics: Philosophical, Theological and Scientific Perspectives. The MIT Press.

Petto, Andrew \& Godfrey, Laurie R. (Eds). 2007. Scientists Confront Creationism: Intelligent Design and Beyond. W.W. Norton \& Co.

Plantinga, Alvin. 1997. "Methodological Naturalism?" Perspectives on Science and Christian Faith. Vol. 49. (September 1997). 143-154.

. 2011. Where the Conflict Really Lies: Science, Religion \& Naturalism. Oxford University Press. 
Polkinghorne, John. 2006. "Where Is Natural Theology Today?" Science and Christian Belief. Vol. 18. 169-179.

Ratzsch, Del. 2001. Nature, Design and Science: The Status of Design in Natural Science. State University of New York Press.

Ratzsch, Del. 2006. "Science and Design." An Interview by Hugo Holbling. The Galilean Library. Available at <http://www.galilean-library.org>. Accessed on December 11, 2013.

Rhoda, Alan. 2007. "Ignorance, Incredulity and the God of the Gaps." Open Future Blog. Available at <http://alanrhoda.net/wordpress/?p=87>. Accessed on September 23, 2015.

Rusbult, Craig. 2004. "God of the Gaps - What Does It Mean?" American Scientific Affiliation. Available at <http://www.asa3.org/ASA/education/origins/gaps2-cr.htm>. Accessed on December 11, 2013.

Russell, Robert J. 2006. "Quantum Physics and Divine Action." The Oxford Handbook of Religion and Science. Eds. Phillip Clayton and Zachary Simpson. Oxford University Press. 579-95. 2008. Cosmology from Alpha to Omega: The Creative Mutual Interaction of Theology and Science. Fortress Press.

2009. "Challenges and Progress in 'Theology and Science': An Overview of the VO/CTNS Series." Scientific Perspectives on Divine Action: Twenty Years of Challenges and Progress. Ed. Robert J. Russell, Nancey Murphy \& William S. Stoeger. CTNS.

Silva, Ignacio. 2014. "Great Minds Think (Almost) Alike: Thomas Aquinas and Alvin Plantinga on Divine Action in Nature." Philosophia Reformata. Vol. 79. No. 1. 8-20.

Snoke, David. 2001. "In Favor of God-of-the-Gaps-Reasoning." Perspectives on Science and the Christian Faith. Vol. 53. No. 9. 152-158.

Sober, Elliott. 2009. "Absence of Evidence and Evidence of Absence -- Evidential Transitivity in Connection with Fossils, Fishing, Fine-Tuning, and Firing Squads." Philosophical Studies. Vol. 143. 63-90.

Sollereder, Bethany. 2015. "A Modest Objection: Neo-Thomism and God as a Cause Among Causes.” Theology and Science. Vol. 13. No. 3. 345-353.

Sorri, Jaakko. 2013. “Aukkojen Jumala?” Areiopagi-verkkolehti. Available at <http://www.areiopagi.fi/aukkojen-jumala/>. Accessed on November 20, 2013. Kojonen (forthcoming). 
Stenger, Victor J. 2004. "Is the Universe Fine-Tuned for Us?" Why Intelligent Design Fails: A Scientific Critique of the New Creationism. Eds. Matt Young and Taner Edis. Rutgers University Press. 172-184.

Swinburne, Richard. 2004. The Existence of God. Oxford University Press.

Tracy, Thomas F. 2006 'Theologies of Divine Action', The Oxford Handbook of Religion and Science. Eds Phillip Clayton and Zachary Simpson. Oxford University Press. 596-611.

Turner, Denys. 2004. Faith, Reason and the Existence of God. Cambridge University Press.

Venema, Dennis. 2012. "The Evolutionary Origins of Irreducible Complexity." Biologos Institute. Available at $<$ http://biologos.org/blog/series/understanding-evolution-theevolutionary-origins-of-irreducible-complexity>. Accessed on September 23, 2015.

Walton, Douglas. 2009. Arguments from Ignorance. Penn State University Press.

Walton, John H. 2009. The Lost World of Genesis One: Ancient Cosmology and the Origins Debate. IVP Academic.

Ward, Keith. 2003. “Believing in Miracles.” Zygon. Vol. 37. 741-750.

Young, Matthew \& Edis, Taner (Eds.) 2006. Why Intelligent Design Fails: $A$ Scientific Critique of the New Creationism. Rutgers University Press. 